\title{
PENGARUH CORPORATE GOVERNANCE TERHADAP KUALITAS ENVIRONMENTAL DISCLOSURE
}

\author{
Masiyah Kholmi* \\ Siti Aminah Sumarji \\ Siti Zubaidah \\ Universitas Muhammadiyah Malang \\ *) Masiyah@umm.ac.id
}

\begin{abstract}
This study aims to examine the effect of corporate governance on environmental disclosure quality in companies listed on the Indonesia Stock Exchange and become PROPER participant for the period 2017. The research sample numbered 25 with purposive sampling technique. Data collection techniques with secondary data. Data is taken in the form of published data on the official website of the Indonesia Stock Exchange. Data analysis uses Partial Least Square, While testing the hypothesis using the outer model and inner model. Based on the results of the study found corporate governance have a positive effect on environmental disclosure quality.
\end{abstract}

Keywords: Corporate Governance, Environmental Disclosure, PROPER

\section{PENDAHULUAN}

Environtmental disclosure merupakan pengungkapan informasi perusahaan yang berhubungan dengan implikasi lingkungan dan aktivitas operasi perusahaan (Deegan et al., 2002). Hal ini berkaitan dengan dampak dari aktivitas perusahaan, dengan mengungkapkan informasi lingkungan, perusahaan akan berkontribusi positif dalam kelangsungan hidup manusia dan lingkungan. Environtmental disclosure perusahaan dapat meningkatkan citra perusahaan, ketertarikan pemegang saham dan pemangku kepentingan. Oleh karena itu, permasalahan penting tentang lingkungan menjadi perhatian di berbagai negara khususnya oleh sebagian perusahaan di Indonesia.

Pada era saat ini, sebagian besar perusahaan menitikberatkan pekerjaan pada penggunaan teknologi yang efisien sehingga terkadang mengabaikan aspek lingkungan. Perusahaan yang menjadi sorotan utama dalam kontribusinya terhadap lingkungan yaitu kasus pencemaran limbah udara pada PT. Rayon Utama Makmur Sukoharjo, selain itu, terjadinya permasalahan IPAL (Instalasi Pengolahan Air Limbah) yang tidak sesuai aturan pada PT. Indotama, dan terjadinya pencemaran air oleh PT. Energi Agro Nusantara. Situasi ini mendorong masyarakat untuk menuntut kesadaran akan pentingnya arti lingkungan dalam menerbitkan tanggungjawab sosial perusahaan yang lebih berkualitas, sehingga permasalahan yang timbul akibat aktivitas industri yang berdampak pada lingkungan dapat terminialisir (Fitriana, 2013).

Menurut Clarkson et al. (2008) perusahaan akan melakukan pengungkapan apabila telah melakukan kinerja lingkungan yang baik. Dorongan kuat dari peraturan dapat memaksa perusahaan untuk melakukan pengungkapan lingkungan. Namun demikian, hingga sekarang belum adanya aturan resmi dalam penyajian laporan pengungkapan lingkungan. Hal ini juga disepakati oleh Jain et al. (2015) yang menyatakan bahwa belum ada peraturan yang jelas sebagai kontrol legislatif mengenai pelaporan CSR di Negara-negara kawasan Asia Pasifik. Sehingga bentuk serta isi laporan yang diungkapkan perusahaan cenderung bervariatif, hal ini yang menyebabkan munculnya kekhawatiran akan kualitas pelaporan lingkungan.

Di Indonesia, peraturan tentang lingkungan terdapat dalam Undang-Undang Nomor 40 Tahun 2007 tentang Perseroan Terbatas. Pasal 74 ayat 1 menyatakan bahwa perseroan yang

EQUITY: Jurnal Ekonomi, Manajemen, Akuntansi | Vol. 22, No. 1 126 DOI: 10.34209/equ.v22i1.901 
menjalankan kegiatan usahanya di bidang dan/atau berkaitan dengan sumber daya alam wajib melaksanakan tanggungjawab sosial dan lingkungan. Selain itu, Pasal 66 ayat $2 \mathrm{c}$ mewajibkan semua perseroan terbatas untuk melaporkan pelaksanaan tanggungjawab sosial dan lingkungan dalam Laporan Tahunan.Untuk melengkapi peraturan- peraturan yang sudah ada di Indonesia pemerintah telah memberikan apresiasi kepada perusahaan yang taat akan lingkungannya dalam bentuk PROPER (Program Penilaian Kinerja Lingkungan). Menurut kementrian lingkungan hidup, Program Penilaian Peringkat Kinerja Perusahaan merupakan salah satu upaya untuk mendorong penaatan perusahaan dalam pengelolaan lingkungan hidup melalui instrumen informasi.

Corporate governance merupakan tata kelola perusahaan yang digunakan sebagai alat untuk mengawasi kinerja perusahaan baik stakeholder maupun investor. Dengan adanya corporate governance yang baik maka akan meningkatkan transparansi dan akuntabilitas perusahaan, sehingga tanggungjawab lingkungan hidup perusahaan akan diungkapkan dapat terpercaya. Terdapat beberapa penelitian terdahulu terkait pengaruh corporate governance terhadap kualitas environmental disclosure, namun masih terdapat ketidak konsistenan hasil, sehingga peneliti tertarik untuk melakukan penelitian menegenai corporate governance terhadap kualitas environmental disclosure. Penelitian ini dilakukan pada perusahaan yang terdaftar di BEI dan menjadi peserta PROPER, pemilihan sampel dilakukan karena perusahaan yang menjadi peserta PROPER diharapkan memiliki komitmen yang lebih besar pada pengungkapan lingkungannya. Penelitian ini bertujuan untuk menguji pengaruh corporate governance terhadap kualitas environmental disclosure pada perusahaan yang terdaftar di Bursa Efek Indonesia dan menjadi peserta PROPER periode 2017.

\section{TINJAUAN PUSTAKA DAN PENGEMBANGAN HIPOTESIS}

\subsection{Teori Agensi (Agency Theory)}

Jensen dan Meckling (1976) menyatakan teori keagenan (agency theory) merupakan teori mengenai hubungan agensi yang muncul ketika satu orang atau lebih (prinsipal) menyewa pihak lain (agen) untuk memberikan suatu jasa dan kemudian mendelegasikan wewenang pengambilan keputusan kepada agen tersebut. Teori ini menyatakan bahwa adanya hubungan ketidakseimbangan informasi (asymmetrical information) antara prinsipal dan agen, karena agen berada pada posisi yang memiliki informasi yang lebih banyak tentang perusahaan dibandingkan dengan prinsipal.

Teori agency menyatakan dengan adanya hubungan ketidakseimbangan informasi, akan terdapat dua kepentingan yang dihadapi oleh manajer, yang pertama yaitu manajer sebagai agen akan dihadapi oleh pilihan dalam menentukan kebijakan dalam memaksimalkan kepentingan para prinsipal yaitu para pemilik perusahaan baik itu dalam jangka panjang maupun jangka pendek atau memilih untuk memaksimalkan kesejahteraannya sendiri. Oleh sebab itu, hal tersebut dapat mengindikasikan manajer bertindak semaunya sendiri tanpa memperdulikan kepentingan pihak prinsipal. Untuk menghindari hal tersebut beberapa penelitian menyatakan teori keagenan dapat dikurangi dengan meningkatkan pengungkapan.

Salah satu cara yang digunakan perusahaan untuk memonitor masalah agensi adalah dengan menggunakan tata kelola perusahaan (corporate governance). Solikhah dan Winarsih (2016) menyatakan corporate governance merupakan mekanisme pengelolaan yang didasarkan pada teori agensi. Dengan adanya konsep corporate governance, pihak manajemen (agen) diharapkan dapat dipercaya dalam mengelola kekayaan pemilik (prinsipal), dan pemilik juga yakin bahwa agen bertindak sewajarnya dan tidak melakukan kecurangan untuk kepentingan agen sendiri sehingga dapat meminimalkan konflik serta biaya keagenan.

\subsection{Environmental Disclosure}

Envirometal Disclosure merupakan pengungkapan informasi yang berkaitan dengan lingkungan hidup di dalam laporan perusahaan (Suratno et al., 2007). Environmental

EQUITY: Jurnal Ekonomi, Manajemen, Akuntansi | Vol. 22, No. 1 
disclosure merupakan pengungkapan sukarela, baik secara kualitatif maupun kuantitatif yang dibuat oleh perusahaan untuk menginformasikan aktivitasnya, di mana pengungkapan kuantitatif berupa informasi keuangan maupun nonkeuangan. Dengan melihat environmental disclosure ini, dapat diketahui perusahaan mana saja yang telah menerapkan tanggung jawab sosialnya. Perusahaan yang menerbitkan evnironmental disclosure yang berkualitas akan memberikan informasi yang baik kepada stakeholder.

Environmental disclosure dikatakan berkualitas ketika informasi yang diungkapkan telah sesuai dengan yang diharapkan oleh stakeholder. Hal tersebut dapat dilihat berdasarkan pengukuran environmental index scorecard yang dilakukan oleh Rupley et al. (2012), dimana pengukuran kualitas environmental disclosure diklasifikasi menjadi 4 (empat) tingkatan strategi lingkungan yaitu, compliance (kepatuhan), pollution prevention (pencegahan polusi), product stewardship (penanganan produk), dan sustainable development (pengembangan berkelanjutan).

\subsection{Corporate Governance}

Corporate Governance adalah suatu sistem, proses, seperangkat peraturan yang mengatur hubungan antara berbagai pihak yang berkepentingan (stakeholder) demi tercapainya tujuan organisasi (IAI, 2015). Corporate governance merupakan mekanisme pengelolaan yang didasarkan pada teori agensi. Dengan adanya konsep corporate governance, pihak manajemen (agen) diharapkan dapat dipercaya dalam mengelola kekayaan pemilik (prinsipal), dan pemilik juga yakin bahwa agen bertindak sewajarnya dan tidak melakukan kecurangan untuk kepentingan agen sendiri sehingga dapat meminimalkan konflik serta biaya keagenan. Tujuan Corporate governance yaitu untuk menciptakan tata kelola perusahaan yang baik serta memberikan nilai tambah bagi stakeholder.

Terdapat 5 asas good corporate governance yaitu: transparansi (transparancy), akuntabilitas (accountability), responsibilitas (responsibility), kewajaran (fairness). Dalam melaksanakan kegiatannya, perusahaan harus senantiasa memperhatikan kepentingan pemegang saham dan pemangku kepentingan lainnya berdasarkan asas kewajaran dan kesetaraan.

Corporate governance dipengaruhi oleh beberapa karakteristik, yaitu :

1. Dewan Komisaris

Dewan komisaris merupakan suatu mekanisme dalam pengendalian internal tertinggi suatu perusahaan yang bertanggungjawab untuk mengelola perusahaan secara efektif (Mutia et al., 2011). Teori agensi menyatakan bahwa dewan komisaris dianggap sebagai mekanisme pengendalian intern tertinggi yang bertanggung jawab untuk memonitor tindakan manajemen puncak (Sembiring, 2005). Teori agensi menjelaskan bahwa ukuran dewan komisaris yang semakin besar akan memudahkan dilakukan pengendalian terhadap agen dan mencegah terjadinya penyimpangan.

2 Komisaris Independen

Komisaris Independen didefinisikan sebagai anggota dewan komisaris yang berasal dari luar emiten atau perusahaan publik yang tidak terafiliasi dengan direksi, anggota dewan komisaris lainnya serta pemegang saham mayoritas dan bebas dari hubungan bisnis yang dapat mempengaruhi kemampuannya untuk bertindak independen atau bertindak semata-mata demi kepentingan perusahaan. Adanya komisaris independen telah diatur dalam peraturan BAPEPAM No: KEP-315/BEJ/07-2001 yang menyatakan bahwa setiap perusahaan publik wajib memiliki komisaris independen untuk mewujudkan tata kelola yang baik. Komisaris independen juga dibutuhkan untuk meningkatkan independensi dewan komisaris terhadap kepentingan pemegang saham maupun kepentingan manajemen. Dengan demikian, semakin besar proporsi dewan komisaris independen, maka kemampuan dewan komisaris untuk mengambil keputusan dalam rangka melindungi seluruh stakeholder semakin objektif (Rupley et al., 2012). 


\section{Multiple-Directorships}

Multiple-Directorships merupakan anggota dewan komisaris yang menjabat sebagai dewan komisaris pada perusahaan lain. Anggota dewan komisaris yang bekerja di beberapa perusahaan akan memiliki kualitas pengungkapan lingkungan lebih tinggi dari pada anggota dewan komisaris yang hanya bekerja di satu perusahaan. Hal tersebut karena anggota dewan komisaris yang menjabat sebagai dewan komisaris di perusahaan lain lebih memiliki pengalaman dalam pengawasan pelaporan lingkungan (Rupley et al., 2012).

4. Komite Audit

Siregar et al. (2013) menyatakan bahwa komite audit merupakan organ pendukung dewan komisaris yang berfungsi dalam membantu dewan komisaris melaksanakan tugasnya. Komite audit merupakan alat untuk melakukan pengawasan, sehingga dapat meminimalisir biaya serta dapat meningkatkan kualitas pengungkapan yang dilakukan perusahaan. Ukuran komite audit yang semakin besar maka diharapkan pengawasan yang dilakukan pada perusahaan akan semakin baik dan dapat meningkatkan pengungkapan lingkungan.

\subsection{Pengaruh Corporate Governance Terhadap Kualitas Environmental Disclosure}

Corporate governance merupakan mekanisme pengelolaan yang didasarkan pada teori agensi. Dengan adanya konsep corporate governance, pihak manajemen (agen) diharapkan dapat dipercaya dalam mengelola kekayaan pemilik (prinsipal), dan pemilik juga yakin bahwa agen bertindak sewajarnya dan tidak melakukan kecurangan untuk kepentingan agen sendiri sehingga dapat meminimalkan konflik serta biaya keagenan. Dengan diterapkannya Good Corporate Governance dalam suatu perusahaan, maka perusahaan tersebut dinilai telah berupaya menyampaikan seluruh informasi kepada para pemangku kepentingan termasuk laporan keberlanjutannya (sustainability report). Dalam penelitian ini corporate governance diproksikan dengan ukuran dewan komisaris, komisaris independen, multiple directorship, dan proporsi komite audit yang dimiliki perusahaan.

Tugas utama dewan komisaris dalam corporate governance yaitu mengawasi dan mengevaluasi dalam pembuatan kebijakan serta pelaksanaan kebijakan tersebut oleh dewan direksi serta memberi nasehat kepada dewan direksi. Dalam teori agensi dijelaskan bahwa dengan ukuran dewan komisaris yang semakin besar maka akan memudahkan untuk melakukan pengendalian terhadap agen serta dapat mencegah terjadinya penyimpangan. Dengan demikian, semakin banyak dewan komisaris dalam suatu perusahaan, maka pengungkapan lingkungan juga akan semakin berkualitas karena adanya sistem pengawasan dan monitoring yang baik dari perusahaan. Berdasarkan penelitian yang dilakukan oleh Rupley et al. (2012), Solikhah dan Winarsih (2016) yang menyatakan bahwa ukuran dewan komisaris berpengaruh positif terhadap kualitas pengungkapan.

Komisaris independen dibutuhkan untuk meningkatkan independensi dewan komisaris terhadap kepentingan pemegang saham maupun kepentingan manajemen. Keberadaan komisaris independen bersikap netral, karena tidak ada pengaruh dari manajemen. Dengan demikian, semakin besar proporsi dewan komisaris independen, maka kemampuan dewan komisaris untuk mengambil keputusan dalam rangka melindungi seluruh stakeholder semakin objektif (Rupley et al., 2012). Berdasarkan penelitian yang dilakukan oleh Solikhah dan Winarsih (2016) yang meneliti mengenai tata kelola perusahaan dan kualitas pengungkapan lingkungan, hasil penelitian tersebut menemukan bahwa adanya hubungan positif antara komisaris independen dengan kualitas pengungkapan lingkungan. Hal tersebut selaras dengan penelitian yang dilakukan oleh Rupley et al. (2012) yang menunjukkan independensi dewan komisaris berpengaruh positif terhadap kualitas pengungkapan lingkungan.

Multiple-directorship merupakan anggota dewan komisaris yang menjabat sebagai dewan komisaris lebih dari satu perusahaan. Dewan komisaris yang menjabat sebagai multiple directorship biasanya akan memiliki pengalaman dan pengetahuan yang lebih banyak di bandingkan dengan dewan komisaris yang hanya bekerja pada satu perusahaan saja. Dalam

EQUITY: Jurnal Ekonomi, Manajemen, Akuntansi | Vol. 22, No. 1 
pengungkapan lingkungan, perusahaan yang memiliki anggota dewan komisaris yang menjabat sebagai multiple directorships akan memiliki kualitas pengungkapan lingkungan lebih baik dibandingkan dengan anggota dewan komisaris yang hanya bekerja di satu perusahaan. Berdasarkan penelitian yang dilakukan oleh Solikhah dan Winarsih (2016) yang meneliti mengenai tata kelola perusahaan terhadap kualitas pengungkapan lingkungan, hasil penelitian tersebut menemukan bahwa adanya hubungan positif antara multiple directorships dengan kualitas pengungkapan lingkungan. Hal tersebut selaras dengan penelitian yang dilakukan oleh (Rupley et al., 2012) yang menunjukkan bahwa terdapat hubungan antara multiple directorships dengan kualitas pengungkapan lingkungan.

Komite audit merupakan alat untuk melakukan pengawasan, sehingga dapat meminimalisir biaya serta dapat meningkatkan kualitas pengungkapan yang dilakukan perusahaan. Ukuran komite audit yang semakin besar maka diharapkan pengawasan yang dilakukan pada perusahaan akan semakin baik dan dapat meningkatkan pengungkapan lingkungan. Berdasarkan penelitian yang dilakukan oleh Rupley et al. (2012) yang meneliti mengenai tata kelola perusahaan terhadap kualitas pengungkapan lingkungan, hasil penelitian tersebut menemukan bahwa adanya hubungan positif antara komite dengan kualitas pengungkapan lingkungan. Berdasarkan uraian di atas, hipotesis penelitian yang diajukan dalam penelitian ini adalah:

H: Corporate Governance Berpengaruh Positif terhadap Kualitas Environmental Disclosure

\section{METODE PENELITIAN}

Jenis penelitian ini merupakan penelitian asosiatif. Dimana penelitian asosiatif dilakukan untuk menganalisis hubungan antar variable dan untuk menguji pengaruh dari variabel independen terhadap variabel dependen. Variabel independen dalam penelitian ini adalah corporate governance sedangakan variable dependen yaitu kualitas environmental disclosure.

Populasi dalam penelitian ini sebanyak 83 perusahaan sektor utama, manufaktur, dan jasa yang terdaftar di BEI. Penentuan kriteria sampel dalam penelitian ini menggunakan teknik purposive sampling. Sampel yang digunakan yaitu perusahaan yang terdaftar di BEI dan menjadi peserta PROPER tahun 2017, perusahaan yang menerbitkan annual report dan sustainability report tahun 2017, sehingga jumlah sampel yang diperoleh sebanyak 25 perusahaan.

Jenis data yang dilakukan dalam penelitian ini adalah data sekunder. Dimana data diperoleh melalui situs resmi Bursa Efek Indonesia, yaitu www.idx.co.id untuk memperoleh daftar perusahaan yang terdaftar di BEI, situs masing-masing perusahaan untuk memperoleh annual report, sustainbility report dan juga website resmi kementrian lingkungan hidup, yaitu http://www.menlh.go.id/proper/ untuk memperoleh daftar perusahaan yang ikut serta dalam program penilaian kinerja lingkungan. Teknik atau metode dalam penelitian ini menggunakan metode dokumentasi.

Teknik dan tahapan analisis data dalam penelitian ini menggunakan PLS dengan alat bantu software WarPLS 6.0. Berikut teknik dan tahapan yang dilakukan:

1. Penilaian outer model atau measurement model

Analisis outer model indikator formatif yaitu dengan syarat pengujian bobot indikator (sigificance of weights). Uji sigificance of weights untuk mengetahui nilai signifikansi indikator dengan variabel. Tingkat signifikan yaitu $P$ value dengan syarat $\leq 0,05$.

2 Penilaian inner model atau structural model

Pengujian model struktural dengan melihat nilai koefisien determinasi (R-Squared), semakin tinggi nilai R-Squared maka semakin baik model prediksi dari model penelitian yang diajukan. Selanjutnya, relevansi prediktif atau nilai Q-Squared yang lebih besar dari nol menunjukkan prediktif yang dipengaruhi (Sholihin dan Ratmono, 2013).

3. Uji hipotesis

EQUITY: Jurnal Ekonomi, Manajemen, Akuntansi | Vol. 22, No. 1 
Pengujian hipotesis menguji hubungan antara variabel independen dan dependen yaitu corporate governance terhadap kualitas environmental disclosure. Adapun persamaan struktural yang digunakan dalam penelitian ini untuk menunjukan pengaruh variabel eksogen dengan endogen:

$$
\begin{array}{ll}
\eta=\beta 1 & \xi 1+\zeta \\
\text { Ket: } & \\
\mathrm{H} & =\text { Variabel laten endogen kualitas environmental disclosure } \\
\xi 1 & =\text { Variabel laten eksogen corporate governance } \\
\beta 1 & =\text { Koefisien pengaruh variabel eksogen corporate governance } \\
& \text { terhadap variabel endogen kualitas environmental disclosure } \\
\zeta & =\text { Error pengukuran }
\end{array}
$$

\section{HASIL DAN PEMBAHASAN}

Hasil olah data dengan menggunakan alat bantu software WarPLS 6.0 diperoleh hasil output sebagai berikut:

1. Outer Model

Analisis outer model dengan model indikator formatif merupakan syarat uji significance of weight. Uji significance of weight digunakan untuk mengetahui nilai signifikan indikator dengan variable. Tingkat signifikan yaitu dengan syarat $\mathrm{P}$ Value dibawah 0,05 .

\section{Tabel 1 Hasil Indicator Weight}

\begin{tabular}{ccccc}
\hline Variabel & Indikator & Nilai koefisien & P Value & VIF \\
\hline $\begin{array}{c}\text { Kualitas Environmental } \\
\text { Disclosure }\end{array}$ & EISC & 1.000 & $<0.001$ & 0.000 \\
\hline
\end{tabular}

Sumber: data diolah tahun 2019

Berdasarkan tabel indicator weight, variabel kualitas environmental disclosure telah memenuhi syarat uji significance of weight dilihat dari nilai P value EISC $<0.001$ dan nilai

VIF senilai 0.000 karena untuk pengukuran variabel kualitas environmental disclosure hanya menggunakan satu indikator.

\section{Penilaian Inner Model}

Dalam pengujian inner model yaitu dengan melihat nilai $R$-squared. Semakin besar nilai $R$ - squared menunjukan semakin baik model prediksi dari model penelitian yang diajukan. Kemudian nilai $Q$-squared yang lebih besar dari nol menunjukan prediktif yang baik pula.

Tabel 2. Nilai Adjusted $R$-squared dan $Q$-squared

\begin{tabular}{lcc}
\hline \multicolumn{1}{c}{ Variabel } & Adjusted $R$-squared & $Q$-squared \\
\hline $\begin{array}{l}\text { as Environmental } \\
\text { Disclosure }\end{array}$ & 0.337 & 0.348 \\
\hline
\end{tabular}

Sumber: data diolah tahun 2019

Berdasarkan tabel 2. diatas, nilai Adjusted R-squared sebesar 0.337 atau 33,7\% yang menunjukan corporate governance dapat menjelaskan varian dari kualitas environmental sebesar 33\%, lalu selebihnya sebesar 67\% dipengaruhi oleh variabel diluar model penelitian. Kemudian nilai $Q$-squared sebesar 0,348 atau $34,8 \%$ yang artinya menunjukan prediktif yang baik karena $Q$-squared lebih dari nol.

a. Model Pengujian Hipotesis

Model pengujian hipotesis yaitu untuk menguji kebenaran dugaan dengan melihat path 
coefficients dan tingkat signifikansi. Tingkat signifikansi yang digunakan dalam penelitian ini yaitu sebesar 5\%. Hipotesis yang digunakan dalam penelitian ini yaitu Corporate governance berpengaruh terhadap kualitas environmental disclosure. Berikut ini merupakan gambar model penelitian dan hasil dari effect size yang telah diperoleh berdasarkan pengolahan data :

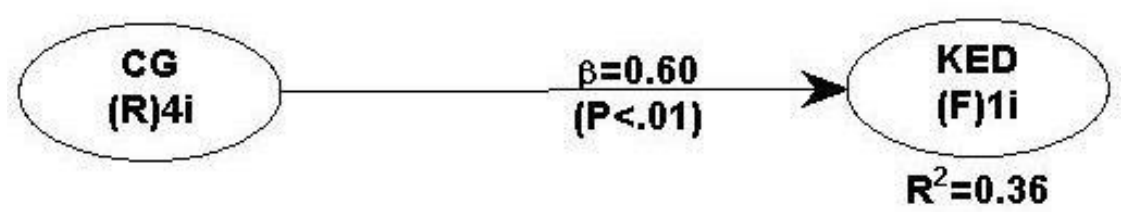

Gambar 1. Output WarpPLS 6.0

Sumber: data diolah tahun 2019

Keterangan :

CG

KED

$=$ Corporate Governance

= Kualitas Environmental Disclosure

Dalam gambar 1 dapat dilihat bahwa variabel Corporate governance yang diporksi dengan ukuran dewan komisaris, komisaris independen, multiple directorship, dan ukuran komite audit memiliki pengaruh yang signifikan terhadap kualitas environmental disclosure dengan nilai $p$-value $<0,001$. Hal ini dilihat dari nilai koefisien beta yang positif yaitu $\beta 0,60$. Angka ini menunjukkan bahwa jika terjadi peningkatan pada penilaian terhadap corporate governance sebesar satu satuan, maka kualitas environmental disclosure akan meningkat sebesar 0,60 . Untuk lebih jelasnya hasil uji disajikan dalam tabel berikut ini :

Tabel 3 Hasil Uji Hipotesis Pengaruh

\begin{tabular}{|c|c|c|c|c|c|}
\hline Hipotesis & Keterangan & $\begin{array}{c}\text { Nilai } \\
\text { Koefisien } \\
\text { Jalur }\end{array}$ & $\begin{array}{c}\mathrm{P} \\
\text { Value }\end{array}$ & $\begin{array}{l}\text { Interpretasi } \\
\text { arah dan } \\
\text { signifikansi }\end{array}$ & Keputusan \\
\hline $\mathrm{H}$ & $\mathrm{CG} \square \mathrm{KED}$ & 0.60 & 0.01 & $\begin{array}{l}\text { Positif, } \\
\text { signifikan }\end{array}$ & Diterima \\
\hline
\end{tabular}

Sumber: data diolah tahun 2019

Berdasarkan tabel 3 diatas, hasil uji hipotesis diterima dengan nilai koefisien positif sebesar 0.60 dengan $\mathrm{P}$ value 0.01 yaitu dibawah 0.05 yang artinya berpengaruh positif signifikan. Model persamaan struktural dalam hipotesis penelitian ini yang menjelaskan hubungan antar konstruk adalah sebagai berikut:

$$
\begin{gathered}
\eta=\beta_{1} \xi_{1}+\zeta \\
\mathrm{KED}=0.60 \mathrm{CG}
\end{gathered}
$$

Berdasarkan hasil olah data statistik, pengujian hipotesis corporate governance diterima dengan tanda nilai koefisien positif signifikan, hal ini menunjukkan corporate governance berpengaruh positif terhadap Kualitas environmental disclosure. Hasil tersebut menunjukkan bahwa semakin baik tata kelola dalam perusahaan maka semakin baik kualitas environmental disclosure yang diungkapkan. Dimana proporsi dewan komisaris sebagai pengukuran indikator corporate governance yang dimiliki oleh perusahaan mempengaruhi

EQUITY: Jurnal Ekonomi, Manajemen, Akuntansi | Vol. 22, No. 1 
dalam melakukan pengungkapan lingkungan. Artinya ketika perusahaan memiliki jumlah dewan komisaris yang banyak, hal tersebut dapat menentukan kualitas pengungkapan environmental disclosure.

Hasil penelitian ini konsisten dengan penelitian yang dilakukan oleh oleh Rupley et al. (2012) dan Solikhah dan Winarsih (2016), namun penelitian ini tidak sejalan dengan penelitian Aliniar dan Wahyuni (2017) dan Aziz (2014) yang menyatakan ukuran dewan komisaris tidak berpengaruh terhadap kualitas environmental disclosure, hal ini dapat disebabkan oleh objek penelitian dan alat ukur yang digunakan berbeda dengan yang peneliti gunakan. Hasil penelitian ini sejalan dengan teori agensi yang menyatakan bahwa dewan komisaris dianggap sebagai mekanisme pengendalian intern tertinggi yang bertanggung jawab untuk memonitor tindakan manajemen. Dengan besarnya jumlah dewan komisaris, hal ini menyebabkan proses monitoring akan semakin baik sehingga pengungkapan informasi sosial dan lingkungan akan semakin luas dan terjamin keandalannya.

Hasil pengujian ukuran dewan komisaris berpengaruh terhadap kualitas environmental disclosure dimungkinkan terjadi karena dewan komisaris dapat melakukan tugasnya untuk mengawasi dan juga sebagai kontrol bagi pihak manajemen. Dalam hal ini manajemen bertanggung jawab untuk meningkatkan efisiensi dan daya saing perusahaan, sedangkan dewan komisaris bertanggungjawab untuk mengawasi manajemen. Sehingga semakin banyak jumlah anggota dewan komisaris dalam suatu perusahaan, berpengaruh terhadap kualitas pengungkapan lingkungan yang dibuat oleh perusahaan.

Hasil penelitian ini menggunakan komisaris independen sebagai pengukuran indikator corporate governance berpengaruh terhadap kualitas environmental disclosure. Hasil penelitian ini sejalan dengan penelitian yang dilakukan oleh Aliniar dan Wahyuni (2017), dan Rupley et al. (2012) yang mengatakan bahwa dewan komisaris independen berpengaruh terhadap kualitas environmental disclosure, namun penelitian ini tidak sejalan dengan penelitain terdahulu yang telah dilakukan oleh Aziz (2014) Solikhah dan Winarsih (2016) yang menemukan bahwa komisaris independen berpengaruh signifikan positif terhadap kualitas environmental disclosure, hal ini dapat disebabkan oleh metode pengukuran, objek penelitian dan alat ukur yang digunakan berbeda dengan yang digunakan oleh peneliti. Dengan keberadaan komisaris independen yang dimiliki perusahaan dapat mendukung prinsip responsibilitas dalam penerapan corporate governance bagi perusahaan dalam memberikan informasi yang lebih baik sebagai wujud pertanggungjawaban kepada stakeholders.

Komisaris independen berpengaruh signifikan terhadap kualitas environmental disclosure dimungkinkan terjadi karena komisaris independen telah melaksanakan tugas dan fungsinya independensinya dengan secara maksimal. Sehingga, semakin banyak jumlah ukuran komisaris independen yang dimiliki perusahaan, maka pengambilan keputusan dalam rangka melindungi pemangku kepentingan dan mengutamakan perusahaan menjadi objektif.

Hasil penelitian ini yang menggunakan multiple directorship sebagai pengukuran indikator corporate governance sejalan dengan penelitian yang penelitian yang dilakukan oleh Solikhah dan Winarsih (2016) dan Rupley et al. (2012) yang menemukan bahwa anggota dewan komisaris yang bekerja di berbagai perusahaan berpengaruh positif terhadap kualitas environmental disclosure. Penelitian ini tidak tidak konsisten dengan hasil penelitian yang telah dilakukan oleh Aliniar dan Wahyuni (2017) dan Aziz (2014) yang menemukan bahwa multiple directorship berpengaruh signifikan positif terhadap kualitas environmental disclosure, hal ini dapat disebabkan oleh metode pengukuran pada variabel dependen yang digunakan berbeda dengan yang digunakan oleh peneliti.

Hasil penelitian ini sejalan dengan teori yang dikemukakan oleh Rupley et al. (2012) Multiple Directorship merupakan anggota dewan yang bekerja di berbagai perusahaan yang cenderung memiliki reputasi dan memiliki nilai tambah dari tipe anggota lain. Dalam pengungkapan environmental disclosure perusahaan yang memilki anggota dewan yang bekerja di beberapa perusahaan akan memiliki kualitas environmental disclosure yang lebih tinggi, hal

EQUITY: Jurnal Ekonomi, Manajemen, Akuntansi | Vol. 22, No. 1 
ini karena multiple directership telah melakukan pelaporan lingkungan di perusahaanperusahaan.

Multiple Directorship berpengaruh terhadap kualitas environmental disclosure dimungkinkan terjadi karena dengan adanya keragaman pekerjaan yang dimiliki suatu dewan komisaris dapat meningkatkan efektivitas dan pemegang saham. Rupley et al. (2012) mengungkapkan bahwa anggota dewan yang bekerja di berbagai perusahaan cenderung memiliki reputasi yang memiliki nilai tambah dari tipe anggota lain, sehingga dalam melakukan pengungkapan lingkungan, perusahaan yang memiliki anggota dewan yang bekerja di perusahaan lain, akan memiliki kualitas yang lebih tinggi akan pengungkapan mengenai lingkungan karena telah mendapat pembandingan dengan perusahaan lain.

Hasil penelitian ini yang menggunakan komite audit sebagai pengukuran indikator corporate governance sejalan dengan penelitian yang dilakukan oleh Rupley et al. (2012) dan Siregar et al. (2013) yang yang menemukan bahwa anggota komite audit berpengaruh positif terhadap kualitas environmental disclosure. Penelitian ini tidak tidak konsisten dengan hasil dengan hasil penelitian yang telah dilakukan oleh Aliniar dan Wahyuni (2017) dan Aziz (2014) yang menemukan bahwa komite audit tidak berpengaruh signifikan terhadap kualitas environmental disclosure, hal ini dapat disebabkan oleh metode pengukuran yang digunakan berbeda dengan yang digunakan oleh peneliti.

Komite audit berpengaruh terhadap kualitas environmental disclosure dimungkinkan terjadi karena pengawasan yang dilakukan oleh komite audit terhadap manajemen dapat dikatakan baik. Dalam hal ini, komite audit mampu mengurangi biaya agensi sehingga mampu untuk meningkatkan kualitas pengungkapan yang ada. Berdasarkan data yang diperoleh, menunjukkan ketika jumlah komite audit yang dimiliki tinggi, perusahaan cendrung tinggi dalam mengungkapkan indeks kualitas environmental disclosure.

Untoro dan Zulaikha (2013) menyatakan bahwa tugas dari komite audit dapat dirasakan sebagai pengawasan atau monitoring kualitas tinggi dan berpengaruh signifikan dalam menyediakan informasi yang lebih terhadap pengguna laporan keuangan. Dengan demikian, dengan adanya proporsi komite audit yang semakin banyak maka diharapkan proses pengawasan yang dilakukan akan semakin baik dan kualitas pengungkapan tanggung jawab sosial yang di ungkapkan akan semakin luas.

Kualitas environmental disclosure yang tertinggi yaitu pada PT. Tambang Batubara Bukit Asam Tbk yaitu sebanyak 40 indeks pengungkapan, dengan jumlah dewan komisaris sebanyak 8, jumlah komisaris independen sebanyak 3, jumlah komisaris yang bekerja di perusahaan lain sebanyak 4, dan jumlah komite audit sebanyak 5. Sedangkan kualitas environmental disclosure terendah dimiliki oleh PT Indo Rama Synthetic Tbk yaitu sebanyak 16 indek pengungkapan, dengan nilai jumlah dewan komisaris sebanyak 5, jumlah komisaris independen sebanyak 2, jumlah komisaris yang bekerja di perusahaan lain sebanyak 2, dan jumlah komite audit sebanyak 3 .

\section{SIMPULAN, KETERBATASAN, SARAN \\ 5.1 Simpulan}

Berdasarkan penelitian yang telah dilakukan mengenai pengaruh corporate governance terhadap kualitas environmental disclosue. Penelitian ini membuktikan bahwa corporate governance berpengaruh positif terhadap kualitas environmental disclosure telah sesuai dengan teori keagenan, dimana perusahaan dengan ukuran dewan komisaris, komisaris independen, multiple directorship, dan ukuran komite audit yang tinggi dapat menjamin pengendalian, pengawasan, serta mendorong pihak manajemen delam mengungkapkan environmental disclosure yang berkualitas.

\subsection{Keterbatasan Penelitian}

Penelitian ini memiliki keterbatasan yang dapat menjadi arah bagi peneliti selanjutnya.

EQUITY: Jurnal Ekonomi, Manajemen, Akuntansi | Vol. 22, No. 1 
Adapun keterbatasan yang dimiliki yaitu pengukuran kualitas environmental disclosure menggunakan content analysis dengan pemberian skor masih bersifat subjektivitas dari peneliti. Selain itu berdasarkan hasil uji $R$-squared variabel corporate governance hanya mampu menjelaskan variabel kualitas environmental disclosure sebesar 33\%, artinya masih ada 67\% indikator lain diluar indikator yang diteliti. Hasil penelitian akan lebih baik jika menggunakan sampel perusahaan di tambah.

\subsection{Saran}

Berdasarkan keterbatasan peneliti yang telah diungkapkan, maka untuk peneliti berikutnya dapat menambahkan variabel lain yang dapat mempengaruhi kualitas environmental disclosure serta penelitian selanjutnya disarankan untuk meminimalisir unsur subjektivitas dalam pengukuran kualitas pengungkapan lingkungan. dengan menggunakan metode lain yang dapat mengurangi tingkat subjektivitas terhadap informasi yang dihasilkan perusahaan dalam laporannya.

\section{DAFTAR PUSTAKA}

Aliniar, D., dan S. Wahyuni. 2017. "Pengaruh Mekanisme Good Corporate Governance (Gcg) Dan Ukuran Perusahaan Terhadap Kualitas Pengungkapan Sustainability Report ". Kompartemen, Vol. 15, No. 1.

Aziz, A. 2014. "Analisis Pengaruh Good Corporate Governance (Gcg) Terhadap Kualitas Pengungkapan Sustainability Report ". Jurnal Audit dan Akuntansi, Vol. 3, No. 2.

BAPEPAM.2001. "Keputusan Direksi PT Busa Efek Jakarta" No. KEP-315/BEJ/2001 tentang Ketentuan Umum Pencatatan Efek Bersifat Ekuitas di Bursa.

Deegan, C., M. Rankin, dan J. Tobin. 2002. "An examination of the corporate social and environmental disclosures of BHP from 1983-1997 A test of legitimacy theory". Accounting, Auditing \& Accountability Journal, Vol. 15, No. 3.

Fitriana, A. 2013. "Pengaruh Kinerja Lingkungan dan Hard Environmental Disclosure Terhadap Return Saham", Jurnal Fakultas Ekonomi dan Bisnis, Universitas Negeri Semarang, Semarang.

IAI. 2015. Etika Profesi dan Tata Kelola Korporat. Jakarta Pusat: Ikatan Akuntan Indonesia.

Jensen, M. C., dan W. H. Meckling. 1976. "Theory of the Firm: Managerial Behavior, Agency Costs and Ownership Structure". Journal of Financial Economics, Vol. 3, No. 4, hlm: 305360 .

Mutia, Evi, Zuraida, dan A. Devi. 2011. "Pengaruh Ukuran Perusahaan, Profitabilitas dan Ukuran Dewan Komisaris terhadap Pengungkapan Corporate Social Responsibility pada Perusahaan Manufaktur yang Terdaftar di Bursa Efek Indonesia". Jurnal Telaah \& Riset Akuntansi, Vol. 4, No. 2.

Rupley, K. H., D. Brown, dan S. Marshall. 2012. "Governance, Media and the Quality of Environmental Disclosure ". Journal Accounting Public Policy, Vol. 31, No. 6. 
Sembiring, E. R. Year. "Karakteristik Perusahaan dan Pengungkapan Tanggung Jawab Sosial: Study Empiris Pada Perusahaan yang Tercatat Di BEJ ". Artikel dipresentasikan pada Simposium Nasional Akuntansi VII, di Solo.

Sholihin, M., dan D. Ratmono. 2013. Analisis SEM-PLS dengan WarpPLS3.0 untuk Hubungan Nonlinier dalam Penelitian Sosial dan Bisnis. Yogyakarta: Andi Offset.

Siregar, I., Lindrianasari, dan Komarudin. 2013. "Hubungan Antara Kinerja Lingkungan Dan Kinerja Komite Audit Dengan Kualitas Pengungkapan Corporate Social Responsibility". Jurnal Akuntansi dan Keuangan, Vol. 4, No. 1.

Solikhah, B., dan A. M. Winarsih. 2016. "Pengaruh Liputan Media, Kepekaan Industri, Dan Struktur Tata Kelola Perusahaan Terhadap Kualitas Pengungkapan Lingkungan ". Jurnal Akuntansi dan Keuangan Indonesia, Vol. 13, No. 1, hlm: 1-22.

Suratno, I. B., Darsono, dan S. Mutmainah. 2007. "Pengaruh Environmental Performance Terhadap Environmental Disclosure dan Economic Performance (Studi Empiris pada Perusahaan Manufaktur yang terdaftar di BEJ periode 2001-2004)". The Indonesian Journal of Accounting Research, Vol. 2 
